\title{
Spraying of Garlic Extract, Fructose and Salicylic Acid Accelerates Bud Burst and Improves Productivity and Fruit Quality of Superior Grapevines Abd-Elall, E. H. Horticulture Department, Faculty of Agriculture, Sohag University, Sohag, Egypt
}

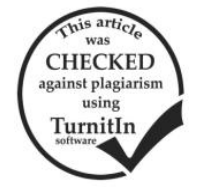

\section{ABSTRACT}

This study was carried out during 2016/ 2017 and 2017/ 2018 seasons on 78 mature self- rooted, 15- years old cane trained Superior grapevines. The selected vines were uniform in vigour as possible. The vines were treated with $4 \%$ garlic extract, $3 \%$ fructose and $300 \mathrm{mg} / 1$ salicylic acid at four times (the last week of Dec., the first week of Jan., the second week of Jan., and the third of Jan.). The purpose of this study was to investigate the effect of these treatments on the time of bud burst, percentages of bud burst, berry setting, fruiting buds, shot berries, growth, productivity and berry quality of Superior grapevines. Results revealed that, the maximum values of these various measurements were found on the vines that were treated with $300 \mathrm{mg} / \mathrm{l} \mathrm{salicylic}$ acid on the first week of Jan. and was beneficial for obtaining an economical yield advancing harvesting date, controlling shot berries and producing fairly good quality of Superior grapes growing under Sohag conditions.

Keywords: Superior Grapevines, garlic extract, fructose, Salicylic acid, bud burst, quality, Yield.

\section{INTRODUCTION}

Grapes consider one of most widely distributed fruit crop is cultivated worldwide (Williams et al., 1994). The total area and the production of vines worldwide were more than 7.5 million hectares and 75 million metric ton fruits, respectively (FAO, 2016). This wide spread distribution of vines is thanks to the large genetic diversity of available grape species and cultivars, as well as the relative low chilling requirements of buds to overcome winter dormancy. The most widespread vine species, Vitis vinifera $\mathrm{L}$, is a temperate climate plant adapted for warm summers and cold winters (Weaver, 1976).

Grape is the second fruit crop in Egypt, incultivated area and productivity preceded only by citrus crops.

Because of the high net return gained by grape growers, its cultivated area grew rapidly in the last two decades. Its acreage still growing, since the more recent statistics revealed that grape fruiting area in Egypt reached 192000 Fed. in 2016 (FAO, 2016). Most of grapes produced in Egypt consumed fresh and the little are used in juice, wine and raisins production.

In Sohag Governorate where the present study was carried out, fruiting area and total production of grapevines during 2016 season reached 520 fed. and 6004 metric ton fruits, respectively. Superior grapevine cv. is a prime and popular grape cv. successfully grown under Egypt conditions. Such grapevine cv. ripens early in the first week of June and sometimes in the last week of May under sandy soil conditions. In addition, it has a greater potentiality of export to foreign markets due to its early in ripening character which reduced competition.

A major obstacle for the economic production of viticulture in Egypt is the insufficient period of chilling temperatures. This problem leads to poor bud break, which in turn results in lowering the yields. The problem thus needs to be overcome with the help of certain rest breaking agents. It is necessary to understand the process of dormancy of the grapevines to apply rest breaking treatments effectively (Lang et al., 1987). Nowadays, hydrogen cyanamide (H2CN2) are recommended in Egypt for budbreak induction of grapevines, however, hydrogen cyanamide is highly toxic. The Environmental Protection Agency of the United States classifies this compound in the highest toxicity category (category I), and it has been under regulatory review by European Union authorities (Settimi et al., 2005). Therefore, there is a necessity of new agents for dormancy break that are easily available, effective, low toxic and used in low concentrations.

Searching for new alternatives for budbreak, Kubota and Miyamuki (1992) verified that garlic paste applied to cane cut surfaces of 'Muscat of Alexandria' grapevines, immediately after pruning, was more efficient than calcium Cyanamid (CaCN2), a substance typically used for vines in Japan. Satisfactory results were also obtained with $20 \%$ garlic oil in 'Pione' and 'Thompson seedless' grapevines (Kubota et al., 2000). Also, Botelho et al. (2007), observed $37 \%$ and $75 \%$ sprouted buds in cuttings of grapevines cv. Cabernet Sauvignon sprayed with garlic extract $3 \%$, submitted to 0 and 168 chilling hours $\left(=7,0^{\circ} \mathrm{C}\right)$, respectively, but this treatment were less effective than hydrogen cyanamide.

Sugar may be utilized as bud break agents as they are safer than cyanamides. The sugar shows no toxic effects or mutagenicity and is a component of human food (Matsuo and Izumori, 2006). The sugar improved the percentage of bud break when applied at $1 \%$ concentration. When the concentration was increased to $3 \%$, percentage, bud break was increased. (Madhab et al., 2011).

Salicylic acid has a pronounce role in reducing the activity of catalase and increasing the release of $\mathrm{H}_{2} \mathrm{O}_{2}$. It is a new plant hormone and has been shown to interfere with the biosynthesis and / or action of ethylene, ABA, and cytokinins. Also, it is responsible for inhibiting abiotic stress (Joseph et al., 2010). Application of salicylic acid has many important regulatory effects on enhancing growth, yield and quality of berries in different grapevine cv.s (Abd El- Kareem, 2009; El- Hanafy, 2011; El- KadyHanaa, 2011 and Mohamed- Ebtesam, 2102).

The present study aimed to investigate the effect of applying the bud break substances salicylic acid, fructose and garlic extract after pruning on the growth and yield structure of Superior grapevines grown under the condition of Upper Egypt.

\section{MATERIALS AND METHODS}

This study was carried out during 2016/2017 and 2017/2018 seasons on 78 mature self- rooted 15-years old cane trained Superior grapevines cv. The selected vines were chosen as uniform in vigour as possible an $\mathrm{d}$ grown in Sohag Fac. of Agric. Experimental orchard located at ElKawthar, Sohag Governorate. The texture of the vineyard soil is sandy and well drained water, since water table depth more less two meters. The chosen vines are spaced at 
$1.75 \times 2.5$ meters apart, cane pruning was followed in the last week of December in both seasons with assistance of $\mathrm{T}$ shape supporting system. The vines were irrigated by drip irrigation system. Vines received all agriculture practice recommended.

\section{Garlic extraction preparation}

Garlic bulbs, was washed with distilled water and dried in shade. They were finely grinded to powder. Fifty grams of garlic in powder form was homogenized by laboratory blender in $200 \mathrm{ml}$ of methanol (96\%) and distilled water $(20: 80 \mathrm{v} / \mathrm{v})$ for $10 \mathrm{~min}$, and then left in dark glass bottles for $72 \mathrm{~h}$ for complete extraction. The garlic extract were filtered through thin cheese cloth sheets. The final extracts were collected separately in other dark glass bottles and exposed to $60^{\circ} \mathrm{C}$ in water bath for $30 \mathrm{~min}$ for methanol evaporation. The collected extracts were then stored in a refrigerator at $5^{\circ} \mathrm{C}$ until needed. Plant extracts was subjected to GC-MS analysis using a Gas Chromatograph (Table, 1) (Singh et al., 2005).

Table 1. Functional components of garlic extracts by GC- MS analysis

\begin{tabular}{lc}
\hline Garlic extract parameters & $\mathbf{( \% )}$ \\
\hline Diallyl sulfide & 33.67 \\
Diallyl disulfide & 10.31 \\
Allyl methyl sulfide & 8.96 \\
3-vinyl-1,2-dithiole-5-cyclohexene & 28.19 \\
Vinyl-1,2-thia-4-cyclohexene & 10.26 \\
Methyl sulfide & 8.61 \\
\hline
\end{tabular}

Four foliar spraying were carried out to vines from each treatment as all the agricultural and horticultural practices were carried out as usual.

\section{- Experimental work:}

The experiment involved thirteen treatments

1-Control (vines sprayed with tap water only).

2-Spraying $4 \%$ garlic extractin the last week of Dec.

3-Spraying $3 \%$ fructose in the last week of Dec.

4-Spraying $300 \mathrm{mg} / \mathrm{l}$ salicylic acid in the last week of Dec

5-Spraying $4 \%$ garlic extract in the first week of Jan.

6-Spraying $3 \%$ fructose in the first week of Jan.

7-Spraying $300 \mathrm{mg} / \mathrm{l}$ salicylic acid in the first week of Jan

8-Spraying $4 \%$ garlic extract in the second week of Jan.

9-Spraying $3 \%$ fructose in the second week of Jan.

10 -Spraying $300 \mathrm{mg} / \mathrm{l}$ salicylic acid in the second week of Jan.

11 -Spraying $4 \%$ garlic extract in the third week of Jan.

12 -Spraying $3 \%$ fructose in the third week of Jan.

13-Spraying $300 \mathrm{mg} / \mathrm{l}$ salicylic acid in the third week of Jan.

Tap water was used for dilution and Triton B was applied at $1 \%$ to all spray solutions as a wetting agent. Foliar spray was carried out using a hand sprayer until drop point to dormant buds.

The experimental design was randomized complete block design (RCBD) with three replicates for each treatment, two vines per each.

\section{Measurements of buds behavior:-}

1- Time of bud burst

2- Percentage of bud burst was calculated by dividing the number of bursted buds on the middle of April by total number of buds left per vine and multiplying the product by 100 .
3- Percentage of fruiting buds was recorded by dividing the number of fruiting buds per vine (i.e. the buds which gave at least one cluster) by total number of bursted buds and multiplying the product by 100 .

Measurements of vegetative growth:

1- Average length of the main shoot $(\mathrm{cm})$ (Last week of May).

2- Numbers of leaves on each main shoot (Last week of May).

3- Average leaf area $\left(\mathrm{cm}^{2}\right)$ was recorded in the twenty leaves from those leaves opposite to the basal clusters (Last week of May) according to the following equation that was outlined by Ahmed and Morsy (1999).

$$
\mathrm{LA}=\mathbf{0 . 4 0}\left(\mathbf{0 . 7 9} \times \mathrm{W}^{2}\right)+15.33
$$

Where: $\mathbf{L A}=$ Leaf area $\left(\mathrm{cm}^{2}\right)$ and $\mathrm{W}$ is the maximum diameter of leaf $(\mathrm{cm})$

Date of first bloom.

Measurements of berry set percentage:

Berry set percentage was calculated by caging five flower clusters on each vine in perforated white paper bags before bloom. After berry setting was completed, the numbers of attached fruitletes as well as the total number of flowers and fruitletes that dropped in the bags were recorded. Percentage of berry set was calculated by dividing number of attached fruitletes by the total number of flowers / cluster (attached berries + dropped flowers and berries ) and multiplying the product by 100 Measurements of harvesting date, yield as well as physical and chemical properties of the berries were recorded.

Harvesting date was recorded when the total soluble solids/ acid index reached 24- 25: 1 according to Weaver (1976). The yield per vine in terms of weight $(\mathrm{kg})$ and number of clusters per vine was registered. Five clusters were taken at random from each vine for determining weight $(\mathrm{g})$ and dimensions (length and width, $\mathrm{cm}$ ) of cluster as well as the following physical and chemical characters of the grapes.

1-Percentage of shot berries was measured by dividing number of small berries by total berries for cluster and multiplying the product by 100 .

2- Average weight of berry (g.)

3 -Averages longitudinal and equatorial of berry $(\mathrm{cm})$.

4-Percentage of total soluble solids in the berry juice was determined by the use of Galilio hand refractometer.

5-Percentage of total acidity in the juice was determine by titration with a known normality of sodium hydroxide solution $(0.1 \mathrm{~N})$ and using phenolphthalein as an indicator then the results were calculated as a $\mathrm{g}$. tartaric acid / $100 \mathrm{~g}$ of juice).

6- Total soluble solids / total acidity were calculated.

7-Percentage of total sugars in the juice was determine by using Lane and Eynon (1965) volumetric method procedure as outlined in (AOAC, 1986).

\section{Statistical analysis:}

All obtained data were tabulated and statistically analyzed according to Mead et al., (1993) and averages of treatments were compared by using new LSD test at 5\% (according to Steel and Torrie, 1984). 


\section{Results}

\section{RESULTS AND DISCUSSION}

\section{Behaviour of buds}

The effect of garlic extract, fructose and salicylic acid spraying on bud burst and fruiting buds percentage and date of bud burst of Superior grapevines during 2016/2017 and 2017/2018 seasons are shown in Table (2).

In general, it can be noticed that all treatments significantly increased the percentage of bud burst and fruiting buds, as well as the advancement of bud burst over the check treatment (control). Using fructose or Salicylic acid was significantly superior to use garlic extract in breaking dormancy and enhancing percentage of bud break and fruiting buds. Spraying garlic extract, fructose and salicylic acid on the first week of Jan., the second week of
Jan., the last week of Dec. and the third week of Jan., in descending order effectively advanced burst and fruiting buds percentage and date of bud burst. Spraying on the first week of Jan. gave an obvious promotion on burst and fruiting buds percentage and date of bud burst. The highest bud burst percentages were recorded with the vines that received salicylic acid at $300 \mathrm{mg}$, followed by $3 \%$ fructose. The fruiting buds percentages were due to $300 \mathrm{mg} / \mathrm{l}$ salicylic acid and 3\% fructose spraying during the two studied seasons, respectively, thus dates of bud burst were $7 \& 9$ Feb. and 6 \& 8 Feb., respectively. On other hand, untreated vines had reduced percentages of bud burst, fruiting buds and delayed bud burst (4 \& 8 Mar.) during the two studied seasons, respectively .

Table 2. Effect of spraying garlic extract, fructose and salicylic acid on the time of bud burst, bud burst \% and fruiting buds \% of Superior grapevines during 2016/2017and 2017/2018 seasons.

\begin{tabular}{|c|c|c|c|c|c|c|}
\hline \multirow{2}{*}{$\begin{array}{l}\text { Dates and } \\
\text { concentrations of }\end{array}$} & \multicolumn{2}{|c|}{ Time of bud burst } & \multicolumn{2}{|c|}{ Bud burst \% } & \multicolumn{2}{|c|}{ Fruiting buds \% } \\
\hline & 2016/2017 & $2017 / 2018$ & $2016 / 2017$ & $2017 / 2018$ & 2016/2017 & $2017 / 2018$ \\
\hline control & 4 Mar. & 8 Mar. & 65.5 & 81.2 & 32.5 & 33.5 \\
\hline $4 \%$ garlic extract on last week of Dec. & 21Feb. & 19 Mar. & 68.6 & 71.0 & 32.7 & 35.5 \\
\hline $3 \%$ fructose on last week of Dec. & 15 Feb. & 12 Feb. & 70.5 & 73.3 & 32.7 & 37.3 \\
\hline $300 \mathrm{mg} / 1 \mathrm{SA}$ on last week of Dec. & 13 Feb. & 10 Feb. & 70.8 & 76.5 & 33.0 & 37.6 \\
\hline $4 \%$ garlic extract on $1^{\text {st }}$ week of Jan. & $11 \mathrm{Feb}$. & 9 Feb. & 80.3 & 70.0 & 32.9 & 43.0 \\
\hline $3 \%$ fructose on $1^{\text {st }}$ week of Jan. & 7 Feb. & 6 Feb. & 83.0 & 88.0 & 33.0 & 45.0 \\
\hline $300 \mathrm{mg} / 1 \mathrm{SA}$ on $1^{\text {st }}$ week of Jan. & 7Feb. & $6 \mathrm{Feb}$. & 84.5 & 91.9 & 33.1 & 46.2 \\
\hline $4 \%$ garlic extract on $2^{\text {nd }}$ week of Jan. & 16 Feb. & 16 Feb. & 72.5 & 70.0 & 33.0 & 41.5 \\
\hline $3 \%$ fructose on $2^{\text {nd }}$ week of Jan. & 9 Feb. & 10 Feb. & 74.5 & 78.8 & 33.0 & 41.0 \\
\hline $300 \mathrm{mg} / 1 \mathrm{SA}$ on $2^{\text {nd }}$ week of Jan. & $9 \mathrm{Feb}$. & $10 \mathrm{Feb}$. & 71.4 & 83.5 & 34.0 & 42.5 \\
\hline $4 \%$ garlic extract on $3^{\text {rd }}$ week of Jan. & $29 \mathrm{Feb}$. & $30 \mathrm{Feb}$. & 67.0 & 71.0 & 33.0 & 34.5 \\
\hline $3 \%$ fructose on $3^{\text {rd }}$ week of Jan. & 23 Feb. & $18 \mathrm{Feb}$. & 68.3 & 70.75 & 33.0 & 36.8 \\
\hline $300 \mathrm{mg} / 1 \mathrm{SA}$ on $3^{\text {rd }}$ week of Jan. & 23 Feb. & $18 \mathrm{Feb}$. & 68.7 & 72.0 & 34.0 & 36.8 \\
\hline New LSD at $5 \%$ & & & 1.4 & 3.8 & N.S & 1.4 \\
\hline
\end{tabular}

Vegetative growth characters.

The effect of garlic extract, fructose at and Salicylic acid spraying on the main shoot length, number of leaves per main shoot and leaf area of Superior grapevines during both seasons are shown in Table (3). In general view, it can noticed that all vines treated had an pronounced effect on the date of first bloom, number of leaves per main shoot and leaf area, over the check treatment (control). Using fructose or Salicylic acid was significantly superior to use garlic extract in increasing the main shoot length, number of leaves per main shoot and leaf area. Spraying garlic extract, fructose and Salicylic acid on the first week of Jan., the second week of Jan., the last week of Dec. and the third of Jan., in descending order effectively increased the main shoot length, number of leaves per main shoot and leaf area. Spraying on the first week of Jan. gave an obvious promotion on increased the main shoot length, number of leaves per main shoot and leaf area. The highest main shoot length was recorded on the vines that received Salicylic acid at $300 \mathrm{mg} / \mathrm{l}$, followed by $3 \%$ fructose. Number of leaves per main shoot and leaf area were due to $300 \mathrm{mg} / 1$ salicylic acid and 3\% fructose spraying during the two studied seasons. On other hand, untreated vines had a reduced main shoot length, number of leaves per main shoot and leaf area during the two studied seasons, respectively.

Table 3. Effect of spraying garlic extract, fructose and Salicylic acid on shoot length (cm.), number of leaves per main shoot and leaf area $\left(\mathrm{cm}^{2}\right)$ of Superior grapevines during 2016/2017and 2017/2018 seasons.

\begin{tabular}{|c|c|c|c|c|c|c|}
\hline \multirow{2}{*}{$\begin{array}{l}\text { Dates and } \\
\text { concentrations of }\end{array}$} & \multicolumn{2}{|c|}{ Shoot length (cm.) } & \multicolumn{2}{|c|}{ Number of leaves per main shoot } & \multicolumn{2}{|c|}{ Leaf area $\left(\mathrm{cm}^{2}\right)$} \\
\hline & 2016/2017 & $2017 / 2018$ & 2016/2017 & $2017 / 2018$ & 2016/2017 & $2017 / 2018$ \\
\hline control & 106.3 & 113.5 & 43.8 & 47.0 & 91.0 & 96.5 \\
\hline $4 \%$ garlic extract on last week of Dec. & 120.2 & 120.4 & 47.0 & 49.0 & 98.0 & 104.0 \\
\hline $3 \%$ fructose on last week of Dec. & 114.3 & 127.5 & 51.3 & 54.0 & 105.1 & 102.0 \\
\hline $300 \mathrm{mg} / 1 \mathrm{SA}$ on last week of Dec. & 114.8 & 128.1 & 50.8 & 53.5 & 105.0 & 109.0 \\
\hline $4 \%$ garlic extract on $1^{\text {st }}$ week of Jan. & 129.0 & 139.8 & 58.3 & 62.8 & 122.0 & 130.5 \\
\hline $3 \%$ fructose on $1^{\text {st }}$ week of Jan. & 129.0 & 143.5 & 61.3 & 65.5 & 132.0 & 135.0 \\
\hline $300 \mathrm{mg} / 1 \mathrm{SA}$ on $1^{\text {st }}$ week of Jan. & 135.0 & 148.5 & 64.8 & 68.3 & 135.5 & 138.7 \\
\hline $4 \%$ garlic extract on $2^{\text {nd }}$ week of Jan. & 117.0 & 129.0 & 52.6 & 58.0 & 105.0 & 113.5 \\
\hline $3 \%$ fructose on $2^{\text {nd }}$ week of Jan. & 122.0 & 135.0 & 55.5 & 62.0 & 117.0 & 122.5 \\
\hline $300 \mathrm{mg} / 1 \mathrm{SA}$ on $2^{\text {nd }}$ week of Jan. & 121.5 & 135.3 & 56.0 & 62.5 & 116.0 & 122.5 \\
\hline $4 \%$ garlic extract on $3^{\text {rd }}$ week of Jan. & 102.6 & 103.5 & 43.0 & 45.5 & 86.5 & 93.3 \\
\hline $3 \%$ fructose on $3^{\text {rd }}$ week of Jan. & 105.4 & 113.5 & 44.0 & 48.5 & 93.5 & 98.1 \\
\hline $300 \mathrm{mg} / 1 \mathrm{SA}$ on $3^{\text {rd }}$ week of Jan. & 104.8 & 114.2 & 45.4 & 49.0 & 94.3 & 99.8 \\
\hline New LSD at $5 \%$ & 4.3 & 4.5 & 3.0 & 3.0 & 3.1 & 2.8 \\
\hline
\end{tabular}


The date of first bloom, berry setting\% and date of harvesting

The effect of garlic extract, fructose and salicylic acid spraying on the date of first bloom, percentages of berry setting and date of harvesting of Superior grapevines during 2016/2017 and 2017/2018 seasons are shown in Table (4). In general view, it can noticed that all treatments had substantial effect on the date of first bloom that were very beneficial in governing the percentage of berry setting and advanced harvesting date, over the check treatment (control). Using fructose or salicylic acid was significantly superior to use garlic extract in advanced the date of first bloom, percentages of berry setting and date of harvesting. Spraying garlic extract, fructose and Salicylic acid on the first week of Jan., the second week of Jan., the last week of Dec. and the third week of Jan., in descending order effectively advanced the date of first bloom, percentages of berry setting and date of harvesting.

Spraying on the first week of Jan. gave asubstantial increase in main shoot length, number of leaves per main shoot and leaf area. The great advancement on the date of first bloom and date of harvesting were recorded on the vines that received Salicylic acid at $300 \mathrm{mg} / \mathrm{l}$, followed by $3 \%$ fructose. The maximum values of percentages of berry setting were recorded on vines treated with $300 \mathrm{mg} / \mathrm{l}$ salicylic acid and 3\% fructose on the first week of Jan. spraying during the two seasons. On other hand, untreated vines had less the percentages of berry setting and resulted in great delay in the start of first bloom and date of harvesting during the two studied seasons.

Table 4. Effect of spraying garlic extract, fructose and salicylic acid on date of first bloom, Berry setting \%and date of harvesting of Superior grapevines during 2016/2017 and 2017/2018 seasons.

\begin{tabular}{|c|c|c|c|c|c|c|}
\hline \multirow{2}{*}{$\begin{array}{l}\text { Dates and } \\
\text { concentrations of }\end{array}$} & \multicolumn{2}{|c|}{ Date of first bloom } & \multicolumn{2}{|c|}{ Berry setting \% } & \multicolumn{2}{|c|}{ Date of harvesting } \\
\hline & 2016/2017 & $2017 / 2018$ & 2016/2017 & 2016/2017 & 2016/2017 & $2017 / 2018$ \\
\hline control & 13Apr. & 19 Apr. & 8.6 & 8.7 & 7 June & 11 June \\
\hline $4 \%$ garlic extract on last week of Dec. & 6 Apr. & $10 \mathrm{Apr}$. & 11.0 & 12.0 & 25 May & 27 May \\
\hline $3 \%$ fructose on last week of Dec. & 23 Mar. & 5 Apr. & 11.6 & 12.6 & 14 May & 16 May \\
\hline $300 \mathrm{mg} / 1 \mathrm{SA}$ on last week of Dec. & 23Mar. & 5 Apr. & 11.6 & 12.6 & 11 May & 16 May \\
\hline $4 \%$ garlic extract on $1^{\text {st }}$ week of Jan. & 23 Mar. & 5 Apr. & 12.4 & 13.2 & 11 May & 11 May \\
\hline $3 \%$ fructose on $1^{\text {st }}$ week of Jan. & 14 Mar. & 21 Mar. & 12.6 & 13.0 & 4 May & 6 May \\
\hline $300 \mathrm{mg} / 1 \mathrm{SA}$ on $1^{\mathrm{st}}$ week of Jan. & 14Mar. & 21 Mar. & 13.0 & 13.5 & 4 May & 6 May \\
\hline $4 \%$ garlic extract on $2^{\text {nd }}$ week of Jan. & 7 Apr. & 17 Apr. & 11.6 & 12.6 & 15 May & 16 May \\
\hline $3 \%$ fructose on $2^{\text {nd }}$ week of Jan. & 21 Mar. & $10 \mathrm{Apr}$. & 12.6 & 12.1 & 8 May & 9 May \\
\hline $300 \mathrm{mg} / 1 \mathrm{SA}$ on $2^{\text {nd }}$ week of Jan. & 21 Mar. & 10 Apr. & 12.7 & 12.5 & 8 May & 9 May \\
\hline $4 \%$ garlic extract on $3^{\text {rd }}$ week of Jan. & 8 Apr. & $15 \mathrm{Apr}$. & 10.7 & 11.1 & 27 May & 29 May \\
\hline $3 \%$ fructose on $3^{\text {rd }}$ week of Jan. & 5 Apr. & $10 \mathrm{Apr}$. & 11.1 & 11.3 & 17 May & 21 May \\
\hline $300 \mathrm{mg} / 1 \mathrm{SA}$ on $3^{\text {rd }}$ week of Jan. & 5 Apr. & $10 \mathrm{Apr}$. & 11.5 & 11.7 & 17 May & 21 May \\
\hline New LSD at $5 \%$ & & & 0.4 & 0.4 & & \\
\hline
\end{tabular}

\section{Yield components:}

Effect of breaking dormancy treatments on number of cluster, cluster weight, dimensions of cluster (length and width) and yield of superior grapevines during both seasons is illustrated in Table 5. All breaking dormancy treatments significantly increased the number, weight of cluster and dimensions of cluster (length and width), consequently significantly increased yield/vine compared to control in both the two studied seasons. $300 \mathrm{mg} / \mathrm{l}$ salicylic acid or fructose 3\% was most effective compared to other treatments. No significant promotion was detected among salicylic acid and 3\% fructose. From economical point of view, the heaviest yield was with vines that sprayed with Salicylic acid (10.8 \& $13.2 \mathrm{~kg} / \mathrm{vine})$ and 3\% fructose $(10.7 \& 13.2 \mathrm{~kg} / \mathrm{vine})$ during the two studied seasons, respectively. The untreated vines produced the lowest ones ( $7.3 \& 7.9 \mathrm{~kg} / \mathrm{vine})$ in both seasons, respectively.

Number of clusters per vine in the first season of study was insignificantly affected by spraying with salicylic acid, fructose and garlic extract. However, in the second season of study number of clusters was significantly affected by spraying with salicylic acid, fructose and garlic extract. The maximum values of number of clusters per vine were recorded on vines treated with $300 \mathrm{mg} / \mathrm{l}$ salicylic acid and 3\% fructose on the first week of Jan. The minimum values were recorded on vines that did not spray.
Dimensions of cluster (length and width) were significantly affected by spraying with Salicylic acid, fructose and garlic extract. The maximum values were recorded on the vines treated with $300 \mathrm{mg} / \mathrm{lSalicylic}$ acidon the first week of Jan. The lowest value was recorded on the control.

\section{Berry quality:}

Data in Tables $(6 \& 7 \& 8)$ clearly show that spraying any of the rest breakages significantly increased weight, length and width of berry, where they significantly reduced the shot berries percentage over the unsprayed ones (control). Moreover, with regarding to the chemical characteristics of the berries, Salicylic acid, fructose and garlic extract they were significantly enhanced the TSS, TSS/acid ratio and reducing sugars percentage and decreased the total acidity over the control. The highest improvement of berry quality was associated with 300 $\mathrm{mg} / \mathrm{lSalicylic}$ acidor $3 \%$ fructose. The heaviest berry weight were $3.53 \& 3.85$ and $3.50 \& 3.84 \mathrm{~g}$ due to 300 $\mathrm{mg} / \mathrm{lSalicylic}$ acid and $3 \%$ fructose spraying, respectively, The lowest values were recorded on the control, in both seasons.

Also, the highest values of TSS/acid ratio were $31.2 \& 32.5$ and $31.1 \& 32.3$ due to $300 \mathrm{mg} / 1$ salicylic acid and $3 \%$ fructose application, the lowest values were recorded on the control, in both seasons. 
Table 5.Effect of spraying garlic extract, fructose and salicylic acid on number of clusters / vine, yield per vine (kg.) and cluster weight (g.) of Superior grapevines during 2016/2017and 2017/2018 seasons.

\begin{tabular}{|c|c|c|c|c|c|c|}
\hline \multirow{3}{*}{$\begin{array}{l}\text { Dates and } \\
\text { concentrations of }\end{array}$} & \multicolumn{2}{|c|}{ Number of clusters / vine } & \multicolumn{2}{|c|}{ Yield per vine (kg.) } & \multicolumn{2}{|c|}{ Cluster weight (g.) } \\
\hline & $2016 / 2017$ & $2017 / 2018$ & 2016/2017 & $2016 / 2017$ & 2016/2017 & $2017 / 2018$ \\
\hline & 26.0 & 27.0 & 7.3 & 7.9 & 300.5 & 311.8 \\
\hline $4 \%$ garlic extract on last week of Dec. & 27.0 & 30.0 & 8.2 & 9.2 & 325.0 & 335.0 \\
\hline $3 \%$ fructose on last week of Dec. & 27.0 & 30.0 & 8.7 & 9.9 & 340.0 & 345.0 \\
\hline $300 \mathrm{mg} / 1 \mathrm{SA}$ on last week of Dec. & 27.0 & 31.0 & 8.7 & 9.9 & 340.8 & 346.0 \\
\hline $4 \%$ garlic extract on $1^{\text {st }}$ week of Jan. & 27.5 & 33.0 & 9.7 & 11.7 & 370.5 & 380.5 \\
\hline $3 \%$ fructose on $1^{\mathrm{st}}$ week of Jan. & 27.5 & 34.5 & 10.7 & 13.2 & 406.0 & 405.0 \\
\hline $300 \mathrm{mg} / 1 \mathrm{SA}$ on $1^{\mathrm{st}}$ week of Jan. & 27.5 & 34.5 & 10.8 & 13.2 & 407.5 & 306.5 \\
\hline $4 \%$ garlic extract on $2^{\text {nd }}$ week of Jan. & 27.0 & 32.0 & 8.7 & 10.1 & 340.5 & 342.5 \\
\hline $3 \%$ fructose on $2^{\text {nd }}$ week of Jan. & 27.0 & 32.0 & 9.0 & 10.8 & 351.0 & 358.5 \\
\hline $300 \mathrm{mg} / 1 \mathrm{SA}$ on $2^{\text {nd }}$ week of Jan. & 26.0 & 32.5 & 9.0 & 10.8 & 352.0 & 323.5 \\
\hline $4 \%$ garlic extract on $3^{\text {rd }}$ week of Jan. & 26.0 & 29.0 & 7.7 & 8.5 & 310.0 & 323.0 \\
\hline $3 \%$ fructose on $3^{\text {rd }}$ week of Jan. & 26.0 & 29.5 & 7.9 & 10.1 & 325.0 & 335.5 \\
\hline $300 \mathrm{mg} / 1 \mathrm{SA}$ on $3^{\text {rd }}$ week of Jan. & 27.0 & 30.0 & 7.9 & 10.2 & 330.0 & 335.5 \\
\hline New LSD at $5 \%$ & $\mathrm{NS}$ & 1.4 & 0.6 & 0.7 & 15.5 & 13.1 \\
\hline
\end{tabular}

Table 6. Effect of spraying garlic extract, fructose and salicylic acid on cluster length (cm), cluster width (cm) and Shot berries \% of Superior grapevines during 2016/2017 and 2017/2018 seasons.

\begin{tabular}{|c|c|c|c|c|c|c|}
\hline \multirow{2}{*}{$\begin{array}{l}\text { Dates and } \\
\text { concentrations of }\end{array}$} & \multicolumn{2}{|c|}{ Cluster length (cm) } & \multicolumn{2}{|c|}{ Cluster width (cm) } & \multicolumn{2}{|c|}{ Shot berries \% } \\
\hline & 2016/2017 & $2017 / 2018$ & $2016 / 2017$ & $2017 / 2018$ & $2016 / 2017$ & $2017 / 2018$ \\
\hline control & 14.6 & 14.8 & 7.1 & 7.2 & 7.8 & 8.6 \\
\hline $4 \%$ garlic extract on last week of Dec. & 15.5 & 15.9 & 8.1 & 8.2 & 6.5 & 6.4 \\
\hline $3 \%$ fructose on last week of Dec. & 16.0 & 16.5 & 8.5 & 9.1 & 6.2 & 5.9 \\
\hline $300 \mathrm{mg} / 1 \mathrm{SA}$ on last week of Dec. & 16.0 & 16.6 & 8.5 & 9.1 & 5.8 & 5.6 \\
\hline $4 \%$ garlic extract on $1^{\text {st }}$ week of Jan. & 16.5 & 17.0 & 9.5 & 9.8 & 4.8 & 3.9 \\
\hline $3 \%$ fructose on $1^{\text {st }}$ week of Jan. & 17.2 & 17.5 & 10.5 & 10.9 & 4.3 & 2.9 \\
\hline $300 \mathrm{mg} / 1 \mathrm{SA}$ on $1^{\mathrm{st}}$ week of Jan. & 17.2 & 17.5 & 10.5 & 10.8 & 3.9 & 2.9 \\
\hline $4 \%$ garlic extract on $2^{\text {nd }}$ week of Jan. & 16.0 & 16.5 & 8.3 & 9.1 & 5.9 & 5.4 \\
\hline $3 \%$ fructose on $2^{\text {nd }}$ week of Jan. & 16.6 & 17.2 & 9.1 & 10.1 & 5.1 & 4.0 \\
\hline $300 \mathrm{mg} / 1 \mathrm{SA}$ on $2^{\text {nd }}$ week of Jan. & 16.6 & 17.2 & 9.3 & 10.1 & 5.2 & 4.3 \\
\hline $4 \%$ garlic extract on $3^{\text {rd }}$ week of Jan. & 15.1 & 15.5 & 7.7 & 7.8 & 6.7 & 7.4 \\
\hline $3 \%$ fructose on $3^{\text {rd }}$ week of Jan. & 15.6 & 16.0 & 8.2 & 8.3 & 6.3 & 6.5 \\
\hline $300 \mathrm{mg} / 1 \mathrm{SA}$ on $3^{\text {rd }}$ week of Jan. & 15.6 & 16.2 & 8.2 & 8.3 & 7.2 & 6.5 \\
\hline New LSD at $5 \%$ & 0.6 & 0.6 & 0.6 & 0.6 & 0.5 & 0.5 \\
\hline
\end{tabular}

Table 7. Effect of spraying garlic extract, fructose and salicylic acid on berry weight (g.), berry weight (g) and berry longitudinal $(\mathrm{cm})$ of Superior grapevines during 2016/2017 and 2017/2018 seasons.

\begin{tabular}{|c|c|c|c|c|c|c|}
\hline \multirow{2}{*}{$\begin{array}{l}\text { Dates and } \\
\text { concentrations of }\end{array}$} & \multicolumn{2}{|c|}{ Berry weight (g) } & \multicolumn{2}{|c|}{ Berry equatorial (cm) } & \multicolumn{2}{|c|}{ Berry longitudinal (cm) } \\
\hline & 2016/2017 & $2017 / 2018$ & 2016/2017 & $2017 / 2018$ & $2016 / 2017$ & $2017 / 2018$ \\
\hline control & 2.95 & 3.01 & 1.55 & 1.48 & 1.86 & 1.88 \\
\hline $4 \%$ garlic extract on last week of Dec. & 3.17 & 3.26 & 1.56 & 1.65 & 1.95 & 2.00 \\
\hline $3 \%$ fructose on last week of Dec. & 3.29 & 3.40 & 1.61 & 1.74 & 2.00 & 2.03 \\
\hline $300 \mathrm{mg} / 1 \mathrm{SA}$ on last week of Dec. & 3.30 & 3.41 & 1.61 & 1.74 & 2.00 & 2.03 \\
\hline $4 \%$ garlic extract on $1^{\text {st }}$ week of Jan. & 3.35 & 3.70 & 1.70 & 1.80 & 2.07 & 2.35 \\
\hline $3 \%$ fructose on $1^{\text {st }}$ week of Jan. & 3.50 & 3.84 & 1.75 & 1.85 & 2.16 & 2.42 \\
\hline $300 \mathrm{mg} / 1 \mathrm{SA}$ on $1^{\mathrm{st}}$ week of Jan. & 3.53 & 3.85 & 1.76 & 1.86 & 2.17 & 2.42 \\
\hline $4 \%$ garlic extract on $2^{\text {nd }}$ week of Jan. & 3.30 & 3.45 & 1.61 & 1.72 & 2.01 & 2.04 \\
\hline $3 \%$ fructose on $2^{\text {nd }}$ week of Jan. & 3.35 & 3.65 & 1.67 & 1.80 & 2.07 & 2.15 \\
\hline $300 \mathrm{mg} / 1 \mathrm{SA}$ on $2^{\text {nd }}$ week of Jan. & 3.35 & 3.68 & 1.69 & 1.80 & 2.08 & 2.16 \\
\hline $4 \%$ garlic extract on $3^{\text {rd }}$ week of Jan. & 3.05 & 3.15 & 1.50 & 1.54 & 1.90 & 1.93 \\
\hline $3 \%$ fructose on $3^{\text {rd }}$ week of Jan. & 3.16 & 3.25 & 1.57 & 1.64 & 1.95 & 2.00 \\
\hline $300 \mathrm{mg} / 1 \mathrm{SA}$ on $3^{\text {rd }}$ week of Jan. & 3.17 & 3.25 & 1.57 & 1.65 & 1.95 & 2.00 \\
\hline New LSD at $5 \%$ & 0.06 & 0.07 & 0.04 & 0.04 & 0.06 & 0.05 \\
\hline
\end{tabular}

Table 8. Effect of spraying garlic extract, fructose and salicylic acid on TSS, total acidity and TSS / acid ratio of Superior grapevines during 2016/2017 and 2017/2018 seasons.

\begin{tabular}{|c|c|c|c|c|c|c|}
\hline \multirow{2}{*}{$\begin{array}{l}\text { Dates and } \\
\text { concentrations of }\end{array}$} & \multicolumn{2}{|c|}{ TSS } & \multicolumn{2}{|c|}{ Total acidity } & \multicolumn{2}{|c|}{ TSS / acid ratio } \\
\hline & $2016 / 2017$ & $2017 / 2018$ & 2016/2017 & $2017 / 2018$ & 2016/2017 & $2017 / 2018$ \\
\hline control & 16.9 & 16.1 & 0.683 & 0.688 & 24.8 & 24.8 \\
\hline $4 \%$ garlic extract on last week of Dec. & 17.4 & 17.6 & 0.642 & 0.642 & 27.1 & 27.4 \\
\hline $3 \%$ fructose on last week of Dec. & 17.6 & 17.8 & 0.621 & 0.622 & 28.3 & 28.7 \\
\hline $300 \mathrm{mg} / 1 \mathrm{SA}$ on last week of Dec. & 17.6 & 18.0 & 0.621 & 0.620 & 28.3 & 29.0 \\
\hline $4 \%$ garlic extract on $1^{\text {st }}$ week of Jan. & 17.9 & 18.2 & 0.602 & 0.597 & 29.7 & 30.4 \\
\hline $3 \%$ fructose on $1^{\text {st }}$ week of Jan. & 18.1 & 18.5 & 0.581 & 0.572 & 31.1 & 32.3 \\
\hline $300 \mathrm{mg} / 1 \mathrm{SA}$ on $1^{\mathrm{st}}$ week of Jan. & 18.1 & 18.5 & 0.580 & 0.570 & 31.2 & 32.5 \\
\hline $4 \%$ garlic extract on $2^{\text {nd }}$ week of Jan. & 17.6 & 17.8 & 0.622 & 0.618 & 28.3 & 28.7 \\
\hline $3 \%$ fructose on $2^{\text {nd }}$ week of Jan. & 17.8 & 18.1 & 0.601 & 0.597 & 29.6 & 30.3 \\
\hline $300 \mathrm{mg} / 1 \mathrm{SA}$ on $2^{\text {nd }}$ week of Jan. & 17.8 & 18.1 & 0.600 & 0.596 & 29.6 & 30.3 \\
\hline $4 \%$ garlic extract on $3^{\text {rd }}$ week of Jan. & 17.2 & 17.5 & 0.663 & 0.666 & 25.9 & 26.2 \\
\hline $3 \%$ fructose on $3^{\mathrm{rd}}$ week of Jan. & 17.4 & 17.8 & 0.643 & 0.648 & 27.1 & 27.4 \\
\hline $300 \mathrm{mg} / 1 \mathrm{SA}$ on $3^{\text {rd }}$ week of Jan. & 17.4 & 17.8 & 0.641 & 0.645 & 27.2 & 27.5 \\
\hline New LSD at $5 \%$ & 0.03 & 0.03 & 0.02 & 0.02 & 0.6 & 0.8 \\
\hline
\end{tabular}




\section{Discussion}

our results show a positive effect of salicylic acid, fructose and garlic extracton grapevines growth and berry quality garlic extracts as shown in table (1) contain substantial amounts of sulfur contain substance (allyl group and mono- di' tri and tetra sulfides), volatiles, antioxidants, vitamins and amino acids, as a processor for the synthesis of all other organic compounds containing reduced sulphur as well as for other biosynthesis pathways such as the formation of ethylene. Also, the great biosynthesis of $\mathrm{GA}_{3}$ and IAA during dormancy period surely reflected on terminating bud dormancy (Miyazak and Yang, 1987).Similar results obtained by Mekway (2008), Botelho et al., (2009), Corrales- Maldonado et al., (2010), Botelho et al., (2010) and Biazi et al., (2010) supported the beneficial effects of plant extracts on terminating bud dormancy and enhancing fruiting of Superior grapevines.

Salicylic acid is a phytohormones stimulate the other plant hormones product especially during stress condition. SA stimulus the synthesis of $\mathrm{H}_{2} \mathrm{O}_{2}$ and reducing biosynthesisof ethylene thus these results could be explained by the effect SA on grapevines (Hayat et al., 2010).Similar results obtained byAbd El- Kareem (2009); El- Kady- Hanaa (2011) and El- Hanafy (2011) emphasized the present results concerning the positive action of salicylic acid on fruiting of Superior grapevines.

The sugars might influence ABA metabolism, which subsequently affected the bud dormancy (Poudel, 2008). In addition, the increasing of yield may be due to the effect of treatments in increasing the percentage of fruiting buds, the increase in the number of cluster per treated vine, which consequently increased the yield/vine. Moreover, the effects of garlic extract, salicylic acid and fructose on improving berry quality could be mainly due to its effect on advancing bud burst and consequently all subsequent stages of early growth cycle and advancing maturity.

The results exhibited a positive effect of sugars on bud dormancy. This sugar can be used as bud breakage agents in grapevines. Hence, $3 \%$ fructose solution showed a potential for use as a commercial bud break agent in the future. The results in this connection were in agreement with those obtained by Madhab et al. (2011) and Ahmed et al. (2014).

\section{REFERENCES}

Abd El- Kareem, A.M. (2009). Relation of fruiting in Crimson seedless grapevines to spraying antioxidants. M. Sc. Thesis Fac. of Agric. Minia Univ. Egypt.

Ahmed, F.F. and M.H. Morsy (1999). A new method for measuring leaf area in different fruit species. Minia J. Agric. Res. Develop. 19. No.1 96- 105.

Ahmed, F.F.; H.I.M. Ibrahim; M.A.M. Abada and M.M.M. Osman (2014). Using plant extracts and chemical rest breakages for breaking bud dormancy and improving productivity of superior grapevines growing under hot climates. World Rural Observations, 6(3): 8-18.
Association of Official Agric.Chemists (1985). Official Methods of Analysis (A.O.A.C.) Twelfth ed. Published by A.O.A.C., Benjamin Franklin Station Washington D.C. U.S.A., pp. 490- 510.

Biazi, L.A.; B. Lipski,; E.D. Silva; O.R. Oliveira; A.T. Sachi and R.A. Peressuti (2010). Lime sulphur, mineral oil and garlic extract to suppress dormancy of kiwi Revistade Ciencias Agroveterinarias 9-58-65.

Botelho, R.V.; A.J. Maia; E.T.P. Pires and M.M. Terra (2009). Effect of garlic extract on bud break of grapevines and in vitro control of causal agent of anthracnose (Elsinoeampelina shear). Revist a Brasileria de Fruitcultura 31, 96-102.

Botelho, R.V.; E.J. Pires; M.F. Moura; M.M. Terra and M.A. Technio, (2010). Garlic extract improves bud break of the Niagra grapevines on subTropical regions 40 Giencia Rural Santa Maria pp. 2282-2287.

Corrales- Maldonado, C.C.; M.A. Telelz; A.A. Gardea; S. Grosxo- Avitia and I. Vargas- Arispuro (2010). Organic alternative for breaking dormancy in table grapes grown in hot regions Amer. J. of Agric., and Bio.- Sci. 5 (2): 143-147.

El- Hanafy, W.M.F. (2011). The role of some antioxidants on improving vines productivity in Red Roomy grapevine vineyard. M. Sc. Thesis Fac. of Agric. Minia Univ. Egypt.

El- Kady- Hanaa, F.M. (2011). Productive performance of Thompson seedless grapevine in relation to application of some antioxidants, magnesium and boron. M. Sc. Thesis Fac. of Agric. Minia Univ. Egypt.

FAO-OIV FOCUS (2016). Food and Agriculture Organization of the United Nations and the International Organisation of Vine and Wine. P: 117.

Hayat, Q.; S. Hayat; M. Irtan and A. Ahmed (2010). Effect of exogenous salicylic acid under changing environment. A review Environ. Expl. Bot. 68: 14-25.

Josephe, B.; D. Jini and S. Sujatha (2010). Insight into the role of exogenous salicylic acid in plants grown under environment. Asian J. of Crop. Sci. 2: 226235.

Kubota, N., and M. Miyamuki (1992). Breaking bud dormancy in grapevines with garlic paste.J. Am. Soc. Hortic. Sci. 117:898-901.

Kubota, N.; M.A. Matthews; T. Takahagi and W.M. Kliewer (2000). Effects of garlic preparations and calcium and hydrogen cyanamides on budbreak of grapevines grown in greenhouses. American Journal of Enology and Viticulture, Davis, v.5, n.4, PP 409-414.

Lane, J.H. and L. Eynon (1965). Determination of reducing sugars by means of Fehlings solution with methylene blue as indicator A.O.A.C. Washington D.C. U.S.A.

Lang, G.A.; J.D. Early; G.C. Martin and R.L. Darnell (1987). Endo-, para-, and ecodormancy: Physiological terminology and Classification for Dormancy Research. Hort. Science 22(3): 371- 377. 
Madhab, R.; R. Mochioka; K. Beppu; P.R. Poudel and I. Kataoka (2011). Effect of rare sugars, methionine, and sea water on "Kyoho" grape bud dormancy release. ASEV Jpn., 22 (3): 127-132.

Matsuo, T. and K. Izumori (2006). Effects of dietary Dpsicose on diurnal variation in plasma glucose and insulin concentrations of rats. Biosci. Biotechnol. Biochem. 70: 2081-2085.

Mead, R., Gurnow, R.N. and A.M. Harted (1993). Statistical Methods in Agric. and Experimental Biology. $2^{\text {nd }}$ Ed Chapman and Hall London pp. 54- 60.

Mekawy, A.Y. (2008). Attempts for breaking Endo dormancy in Red Roomy Grapevines. M. Sc. Thesis Fac. of Agric. Minia Univ. Egypt.

Miyazak, J.H. and S.F. Yang (1987). The methionine selvage pathway in relation to ethylene and polyamine synthesis. Phyiologia planetarium 69: 366-370.

Mohamed- Ebtesam, S.E. (2012). Response of Banaty grapevine to some ethryl, nutrient and antioxidant treatments. Ph. D. Thesis Fac. of Agric. Minia Univ. Egypt.

Poudel, P.R. (2008). Evaluation and utilization of grape germplasms native to Japan. Doctoral Thesis, Ehime University, Japan.
Settimi, L.; F. Davanzo; G. Miceli; D. Richmond and G.M. Calvert (2005). Update: Hidrogencyanamide-related Ilnesses-Italy, Morbidity and Mortality Weekly Report. Atlanta, 54: 405-408.

Singh, B.; A. Sahoo; R. Sharma; T.K. Bhat (2005). Effect of polethylene glycol on gas production parameters and nitrogen disappearance of some tree forages. Anim. Feed Sci. Technol., 123/124 (1): 351-364

Steel, R.G. and J.H. Torrie (1984). Principals and Procedure of Statistics .Ms. Graw- Hill Co. Singapore, $2^{\text {nd }}$ Ed. 633 pp.

Weaver, R.J. (1976). Grape Growing. A Wiley Interscience Publication John Wiley \& Davis, New York, London, Syndney, Trontc PP.160-175.

Williams, L.E.; N.K. Dokoozlian and Wample, R. (1994). Chapter 4 : Grape pp. 85- 133. IN handbook of Environmental Physiology of Fruit Crops Volume I: Temperate Crops, Schaffer, B \& Andersen, P.C. (eds.). CRC Press, Boca Raton, Florida, U.S.A.

تأثيرالرش بمستخلص الثوم، الفركتوز وحمض السالسليك لتحسين كسر سكون البراعم وانتاجية العنب السوبريور عماد الاين حافظ عبدالعال جامعة سوهاج ـ كلية الزراعة ـ قسم البساتين

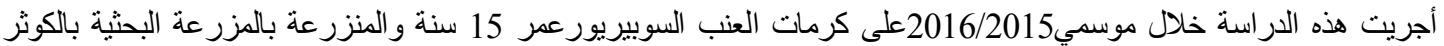

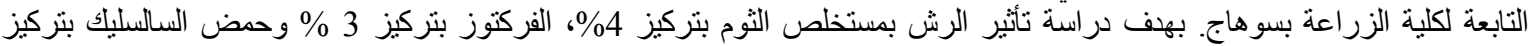

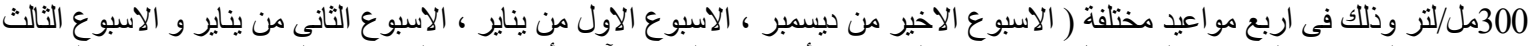

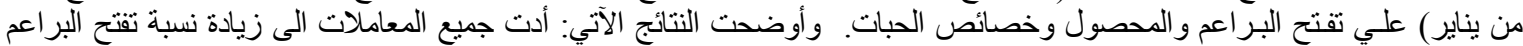

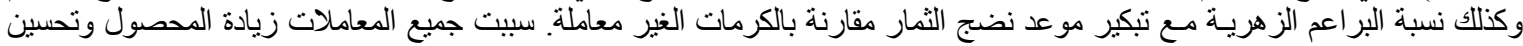

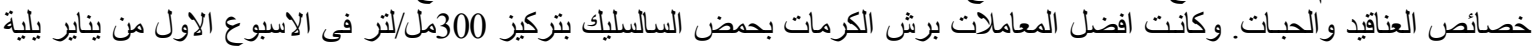

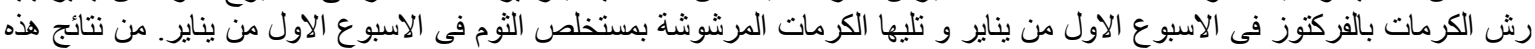

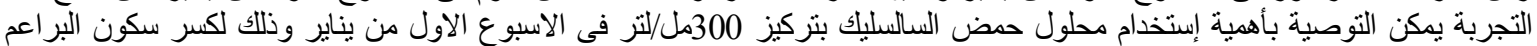
وتحسين تقتح البر اعم وزيادة المحصول وتبكير النضج. 